\title{
'But let justice roll down like waters, and righteousness like an ever-flowing stream' (Am 5:24). Social justice versus cult criticism in Amos (5:21-24) and Isaiah (1:10-20): A trauma perspective
}

\begin{abstract}
Author:
Alphonso Groenewald ${ }^{1}$ (1)

Affiliation:

${ }^{1}$ Department of Old Testament Studies, Faculty of Theology and Religion, University of Pretoria, Pretoria, South Africa

Research Project Registration: Project Leader: A. Groenewald Project Number: 02428024

\section{Description:}

This research is part of the project 'Prophetic literature through the lens of Trauma and Disaster studies', directed by Prof. Dr Alphonso Groenewald Department of Old Testament Studies, Faculty of Theology, University of Pretoria.
\end{abstract}

\section{Corresponding author:} Alphonso Groenewald, alphonso.groenewald@up. ac.za

\section{Dates:}

Received: 26 June 2019

Accepted: 22 July 2019

Published: 19 Nov. 2019

How to cite this article:

Groenewald, A., 2019,

'"But let justice roll down like waters, and righteousness like an ever-flowing stream" (Am 5:24). Social justice versus cult criticism in Amos (5:21-24) and Isaiah (1:10-20): A trauma perspective', HTS Teologiese Studies/Theological Studies 75(3), a5629. https://doi.org/ 10.4102/hts.v75i3.5629

\section{Copyright:}

(c) 2019. The Authors. Licensee: AOSIS. This work is licensed under the Creative Commons Attribution License.

\section{Read online:}

Scan this QR
code with your
smart phone or
mobile device
to read online.

The focus of this article is on the cult-critical statement(s) in Amos (5:21-24) and Isaiah (1.10-20). The title of this article inevitably leads us to the question of the relationship between the practice of the cult on the one hand and ethics on the other hand, namely the 'either-or' dilemma which exegetes face in the interpretation of these texts. This article should therefore be seen as part of the on-going debate of the significance of the prophetic understanding of the role of the cult versus Israel's ethical considerations. Furthermore, an overview of important insights from trauma studies, which are applied to the cult-critical statements in the books of Amos and Isaiah, is given.

Keywords: cult-criticism; Isaiah; Amos; cult; ethics; trauma lens.

\section{Introduction}

Since the beginning of his academic career, Eben Scheffler ${ }^{1}$ has reflected on the question of justice versus injustice from the perspective of different biblical texts. In a number of publications focussing on texts from both the Hebrew Bible (HB) and the New Testament, he highlights the need for justice and righteousness. ${ }^{2} \mathrm{He}$ infers that the biblical text(s) has a clear position regarding the socially weak in society, and he links this to the concept of 'justice'. Scheffler infers (2013b):

[T] he demand for even-handed justice for the rich (Ex 23:2-3) and the poor (Ex 23:6) is probably rendered in Deuteronomy 24:17, focusing on the stranger, widow (whose garment may not be taken as a pledge) and orphan. The emphasis is here on these well-known categories of poor people and the measure is once again motivated by reference to the Israelite's slavery in Egypt and their liberation by Yahweh their God (Dt 24:17). (p. 8)

With regard to historical Jesus scholarly studies, Scheffler (2015c) mentions that a certain consensus exists regarding, inter alia, the following notion:

$[T]$ hirdly justice for all (not in the sense of quid pro quo but in the contemporary Jewish sense of acceptance and caring for all that suffer in society). These three aspects can be condensed even more, as Jesus himself did, in the Golden Rule (Matt 7:12; Luke 6:31) and the command to love God and the fellow human being (Mark 12:29-31; Matt 22:37-40; Luke 10:27-371). (pp. 265-266) ${ }^{3}$

The following quotation from Scheffler (2015b) links to the topic being addressed in this contribution:

However, as far as reconciliation is concerned it should to my mind be noted that a reconciliatory process is most often the logical consequence after forgiveness has occurred. Interestingly, in the Louw and Nida New Testament Dictionary, reconciliation and forgiveness are discussed as part and parcel of the same semantic field (1988:502-503). This corroborates with Jesus' view that one should leave one's sacrifice at

1.This contribution is dedicated to his friend and colleague Prof. Dr. E.H. Scheffler, whom he appreciates as a scholar and exegete of both Old and New Testament Studies. Eben Scheffler wrote his dissertation in New Testament Studies (University of Pretoria 1988), and it was published in 1993 with the title 'Suffering in Luke's Gospel'.

2.See, for example, a number of his publications: 1990:252-267; 2005:97-115; 2009:1-17; 2011a:192-207; 2011b:115-135; 2012:480496; 2013a:129-153; 2013b:1-14; 2014:579-596; 2015a:1-9; 2015b:1-10; 2015c:261-296; 2016a:91-115; 2016b:189-217 2017:160-174; 2018:501-517.

3.With regard to the Belhar Confession, Scheffler (2015c:273) makes the following important statement, in which he emphasises the need for social justice towards the socially weak in society: 'The Belhar Confession (which originated in the context of the protest against apartheid) is the only church confession being adopted by some churches that contains elements of the historical Jesus' own religion or teaching. Amongst others, it emphasises justice, peace, God's love for the poor, prisoners, the blind, strangers, orphans, widows, the downtrodden and all sufferers (see www.rca.org/resources/confession-belhar for the full text). Ironically, this confession originates from the heart of the Dutch Reformed Church in South Africa, the very same church that still struggles to get it adopted as a confession of its own'.

Note: The collection entitled 'Eben Scheffler Festschrift', sub-edited by Jurie H. le Roux (University of Pretoria) and Christo Lombaard (University of South Africa). 
the altar (thereby making the ritual service to God second priority [my emphasis]) and reconcile with the brother if the latter feels wronged (Mt 5:24). (p. 6)

The ethical aspects of worship had already been an important emphasis in his doctoral thesis: 'The Pharisees care about clean cups, but not about almsgiving (11:39-41); they care about tithes, but not about justice [my emphasis] and the love of God (11:42/ / Mt 23:23) ...' (Scheffler 1993:114).

Amos and Isaiah ${ }^{4}$ - two of the most well-known prophetic books from the $\mathrm{HB}$ - at all times have inspired people who decry injustice and oppression. Although the 'original' meaning of these texts may (may not) have been of any interest to the people who use these texts to work and preach against injustice, they are especially committed to reading and interpreting these prophetic texts from their own context and for those who suffer injustice. These books have often been used to criticise the systemic abuse of the most vulnerable by those who are in power, as well as to condemn any form of religious faith that functions without ethical behaviour (Carrol Rodas 2011:32; cf. also Carrol Rodas 2001:77-96; Udoekpo 2017:xvii).

Martin Luther King Jr. referred to the book of Amos in his landmark 'I have a Dream' speech. In this speech, which was given at the Lincoln Memorial in August 1963 during the Civil Rights Movement in the USA, he quoted Amos 5:24: 'Let justice roll down like waters, and righteousness like an ever-flowing stream'. Given its strong appeal to social justice, the book of Amos - as well as the book of Exodus - had a major impact upon the development of various liberation theologies $^{5}$ in different countries of the world (Latin American, African, as well as African American and Hispanic in the USA) (Stulman \& Kim 2010:197-198; cf. also Carrol Rodas 2011:32-33; Osuagwu 2016:39; Udoekpo 2017:xvii).

This type of interpretation and textual reading highlight the challenge one has to engage prophetic texts with the current modern-day life situations. Furthermore, it forces the reader - moreover the exegete - to consider the potential power the biblical text has to empower modern-day traumatised communities who suffer and experience trauma as a result of economic and other injustices (Carrol Rodas 2011:33). However, these texts do encourage us to reflect not only upon the current socio-economic hardships and political realities, which cause suffering and trauma, but also upon the experiences of trauma and disaster within these texts.

\footnotetext{
4.With regard to Isaiah, Stulman and Kim (2010:28) infer as follows: 'Isaiah's manifold oracles aligned the powerful and the powerless, the local and the international, the rich and the poor. All wrongdoings and frailties were publicly exposed regardless of socioeconomic status or political rank, although, in keeping with the prophetic tradition, Isaiah reserved his severest criticism for political and religious leaders'.

5.In this regard, Migliore (2014:63) infers as follows: ' $[m]$ any African Americans, Hispanics, and women read Scripture through Third World eyes, and this presents a deep challenge to First World readers, who all too often expect Scripture to endorse their comfortable, middle-class way of life. Training in a rich contextual reading of Scripture thus demands an ongoing ecumenical conversation and the Spirit-given courage "to hear the voices of people long silenced"'. In defining various liberation courage "to hear the voices of people long silenced"'. In defining various liberation
theologies, Rowland (1999:6) remarks as follows: 'A constant refrain of all the different theologies, Rowland (1999:6) remarks as follows: 'A constant refrain of all the different
approaches which are grouped together under liberation theology is that the approaches which are grouped together under liberation theology is that the
perspective of the poor and the marginalised offers another story, an alternative to perspective of the poor and the marginalised offers another story, an alternative to
that told by the wielders of economic power whose story becomes the "normal" that told by the wielders of economic power whose story becomes the "normal"
account' (cf. also Gutierrez [1999:19-38] regarding the task and content of liberation account' (cf.
theology).
}

\section{Trauma studies and Biblical studies}

In the last two to three decades, there has been an exponential increase in the interest by theologians and biblical scholars to use the category of trauma to interpret the suffering experienced by people.

According to Frechette and Boase (2016:12), this is the result of a movement which had started in the 1970s as biblical scholars developed an interest in the insights offered by different fields of study in terms of the psychological, sociological, economical and political dimensions of human suffering (cf. also Groenewald 2017:56; O'Connor 2010:38). In this regard, it is worth mentioning an innovative and important study which was published in 1974 by the well-known German Old Testament scholar Westermann (1974:20-38). In this study (which was originally published in German), Westermann acknowledges the theological significance of the function of the lament in the $\mathrm{HB}$ and infers as follows: 'the lament is the language of suffering; in it suffering is given the dignity of language: It will not stay silent!' (1974:31; cf. also Frechette \& Boase 2016:12-13; Groenewald 2017:56). It is important to emphasise that 'the cry of lament is not a cry of despair but is a form of hope that involves turning to God' (Katongole 2017:104); in other words, the lament gives a voice to the suffering as experienced by either the individual or the community (Westermann 1974:31; cf. also Carlson 2015:57-58). ${ }^{6}$

A further important development which influenced this hermeneutical shift towards the human dimension(s) of the text was the emergence of liberation theology ${ }^{7}$ - especially with its emphasis on different aspects of oppression (Frechette \& Boase 2016:12; Groenewald 2017:56). Although a hermeneutics of trauma interrelates with all the abovementioned approaches, it also offers new understandings of the individual, collective and systemic dimensions of experiences of suffering and trauma. It is important to emphasise that trauma as a hermeneutical perspective is not a methodological approach as such, but rather a heuristic device, ${ }^{8}$ which opens the eyes of the biblical exegete for all

6. . In this regad, Katongole (2017:97-98) infers as follows: "If theology is about the truth of our lives and how this is connected to our experience of God, then the lament songs, poems, and art represent a crucial theological moment and nexus. These songs and poems do not have a pre-theological content; they are the very content and form of the people's encounter and engagement with God. They are not merely background material to our theology; they are the very locus within which the theological experience and expectations of our people are expressed'

7.In this regard, Gutierrez (1988:xix) remarks as follows: 'Behind liberation theology are Christian communities, religious groups, and peoples, who are becoming increasingly conscious that the oppression and neglect from with their faith in Jesus Christ (or, speaking more generaly, with their religious faith). These concrete, real-life movements are what give this theology its distinctive character; in liberation theology, faith and life are inseparable. This unity account for its prophetic vigor and its potentialities'. Cf. Moltmann (1999:48): 'liberation presupposes real, economic, political and cultural oppression, and is aligned towards a life in freedom and justice. It talks about a historical process, not a static condition The process of liberation is sustained by "the movement of the people". Theology is reflection on this movement in the light of the gospel. Liberation theology is contextually localized and conditioned, deliberately so. Its locus theologicus - its Sitz im Leben - is the suffering of the poor. Participation in the movement of the people goes ahead of the theology: first orthopraxis, then orthodoxy! The church participates in the movement of the people by virtue of its "preferential option for the poor". Liberation theology uses sociological analyses in order to expose the causes of Liberation theology uses sociological analyses in order to expose the causes of poverty (e.g. the dependence theory, which dimperialism colvation history; it testifies to the whole of salvation for the whole of this world'.

8.0'Connor (2010:38) remarks as follows: 'They serve as an "heuristic" or "finding" device. They offer spectacles to "find" what is hidden beneath the opaque surfaces of human suffering'. 
the connections that exist between historical events of suffering and their literary representations. Furthermore, this heuristic framework establishes a relationship between traumatic experiences and the production and appropriation of texts being informed by the experiences of trauma. A hermeneutics of trauma highlights the fact that language can respond to traumatic experiences of disaster in such a way that it not only corresponds to the effects this trauma and disaster ${ }^{9}$ had on the human mind, but also corresponds to the language that develops from this experience that creates the necessary mechanisms of survival, recovery and resilience (Frechette \& Boase 2016:12-13; Groenewald 2017:56).

The new perspectives trauma and disaster studies bring into discussion also raise new challenges for a theological discourse of pain and suffering (Groenewald 2017:56, 2018:95). New questions will undoubtedly be asked as the focus in this debate will shift to transform old discourses about pain and suffering. Therefore, Rambo (2010:5) infers that 'theologians following the conversations about trauma have started to think that trauma calls for a distinctive theological articulation. Unique dimensions of trauma move theology in new directions'. Trauma - when understood in this manner - is not only the focus of the fields of psychology and counselling but also an integral part of theological discourses, and therefore, it challenges all theological understanding profoundly. Although the concept of trauma has become conventional in many different contexts, the 'use of trauma theory in the field of biblical studies is still in its infancy' (Janzen 2012:238).

This integration of trauma and disaster theory into the theological discourse has given exegetes an opportunity not only to integrate various academic subjects and their respective literature methodologies but also to open more possibilities for interdisciplinary research (Groenewald 2018:95). Becker (2014:25) aptly infers that through literature studies, 'we can analyse more in detail how far trauma phenomenology can be used in our understanding of individuals as well as the collective experience of disaster, catastrophe and trauma'. Trauma and disaster studies have made us deeply aware of the impact trauma can have on an individual or on the collective group - whether it is experienced directly or indirectly. An ancient text, like the $\mathrm{HB}$, provides us with textual possibilities on how Israel and Judah dealt with experiences of disaster and trauma. Through their literary echoes, which we have in the texts of the $\mathrm{HB}$, we do not only encounter their traumatic experiences in what is said in a straightforward manner, but even more in the unsaid (Esterhuizen 2017:4, 8; cf. also Groenewald 2017:58).

Theologians and biblical scholars, who are being challenged by the suffering and violence present in our sacred texts, have turned to trauma and disaster theory to attain to a theological understanding thereof (Groenewald 2018:95). ${ }^{10}$

9.With regard to the experience of being overwhelmed by 'disaster', Smith Christopher (2002:79) infers as follows: "'disasters" only become "disastrous" for people when the events exceed the ability of the group to cope, redefine, and reconstruct: "we may speak of disaster when actors in modern societies increasingly lose thei capacity to define a situation that they see as serious or even worrying through
traditional understandings and symbolic parameters"'.

10.An important book, which explores trauma and disaster hermeneutics for both the Old and New Testament, was published by Carr (2014).
Trauma and disaster theory gives the exegete a specific perspective or lens to interpret these sacred texts, as well as to reconsider their central theological perspectives which they offer (Rambo 2010:5).

I find Morrow's insights in trauma theory particularly helpful for the analysis of the specific two texts which will be referred to in this contribution. According to Morrow, it is possible to define trauma 'as (violent) stress that is sudden, unexpected, or non-normative, exceeds the individual's perceived ability to meet its demands, and disrupts various psychological needs' (Morrow 2011:281). Morrow (2011) emphasises that in this definition, the concept of 'disruption' is quite helpful to understand many biblical texts, as:

[O]ne of the well-known effects of trauma is its capacity to shatter a previously constructed sense of self. Both for groups and individuals seeking recovery, it is of primary importance to find ways to assert control over the violence that is frequently internalized as various forms of self-hatred and ongoing syndromes of disintegrating experiences. (p. 281)

If it is interpreted in this way, we can assert that the concept of trauma refers to an experience of 'severe dislocation', subsequently causing the 'constructed sense of self' to be shattered.

Morrow's concept of disruption versus recovery links to what Janoff-Bulman (1999:305-306) would define as 'rebuilding shattered assumptions'. In her opinion, it is important to understand the role which fundamental assumptions ${ }^{11}$ play in our lives to comprehend our coping processes and outcomes. Traumatic life events challenge - even shatter - these basic beliefs or assumptions. These fundamental assumptions that were guiding us through life seem totally inadequate during these times of trauma (Janoff-Bulman 1999:311). This crisis, which is typical in the aftermath of extreme life events, calls for a renewal of these fundamental assumptions (JanoffBulman 1999:305-306; cf. also 1992:115ff.). This process of rebuilding can be depicted with the term 'resilience' - an important concept used in trauma theory. ${ }^{12}$ To be resilient indicates the remarkable capacity of trauma survivors to survive and cope with extreme tragic experiences. To be resilient indicates the painful process of re-establishing some of the prior assumptions as well as a reappraisal of events in a positive, meaning-making way (Janoff-Bulman 1992:140). ${ }^{13}$

The term resilience has become important in trauma and disaster studies' application in the analysis of biblical texts 11.According to Janoff-Bulman (1992:6), these fundamental assumptions (i.e. just-
world beliefs) are 'abstract beliefs about ourselves, the external world, and the
relationship between the two'. She proposes that these assumptions about life
relate to the following three aspects: (1) the benevolence (nature) of the external
world, (2) its meaningfulness of this world (i.e. the good and bad outcomes) and ( 3 )
our self-worth or beliefs about ourselves (cf. also Janoff-Bulman 1999:306). If they
are '[t]aken together, these beliefs reflect the convictions that the world, people,
and self are basically good and that life makes sense insofar as benefits and burdens
are distributed in proportion to an individual's just deserts' (Rumfelt 2011:326).
12.Carr (2014) wrote a book with the significant title: Holy Resilience: The Bible's
Traumatic Origins.
13.In this regard, Janoff-Bulman (1992:140) infers as follows: 'Yet the cognitive strategies
used by trauma survivors attest to the possibility for some human choice even in the
face of uncontrollable, unavoidable negative outcomes. These choices reside in the
interpretations and reinterpretations, appraisals and reappraisals, evaluations and
reevaluations made of the traumatic experience and one's pain and suffering'. 
(Schreiter 2016:193). This is indeed the case in, for example, Kathleen O'Connor's work on trauma and the book of Jeremiah (2012). According to her, the literary function of the book of Jeremiah is to encourage people to survive, to give them hope - even when the words themselves seem hopeless. The literary violence of the book of Jeremiah offers victims of violence the capacity to express themselves to undermine the brutality of violence that they have experienced. Therefore, '[ $v$ ]iewed from this perspective, Jeremiah is a work of resilience, a book of massive theological reinvention, and a kind of survival manual for a destroyed society' ( $\mathrm{O}^{\prime}$ Connor 2012:x). In his book Holy Resilience, David Carr (2014:8-9) highlights the fact that ancient Israel did not only suffer as a result of periods of crises but also their existing group identity was totally torn apart as a result of these crises. The subsequent catastrophes which they experienced did not only cause individuals to suffer but also shatter their identities, and as a result, it is required of them to come to a new understanding of themselves. In the view of Schreiter (2016:201), one can live from resilience, or, to put it differently, resilience manifests itself in an act of identity affirmation and formation; in other words, 'rebuilding shattered assumptions'.

\section{Cult-criticism and ethics}

The focus of this article is on the cult-critical statement(s) in Amos and Isaiah. But before we pay attention to these two texts in more detail, it is important to make some broad remarks regarding the cult and some of its key concepts. ${ }^{14}$ Furthermore, the title of this article inevitably leads us to the question of the relationship between the practice of the cult on the one hand and ethics on the other hand. This could be described as the 'either-or' dilemma, which exegetes face in the interpretation of these texts. ${ }^{15}$ This section should therefore be seen as part of the on-going debate of the significance of the prophetic understanding of the role of the cult versus Israel's ethical considerations. ${ }^{16}$

During the late 19th century and in the first half of the 20th century, the religion of the so-called classical prophets was often regarded as a more internalised spiritualised religion (anti-cultic), ${ }^{17}$ which stands in direct opposition to the more

14.Given the limitations of the length of this publication, a very broad overview will be given. Even as I draw from other scholars, my discussion of the ethical dimension of the cult draws largely from - and closely follows - an extensive study done by Hrobon (2010), in which he focuses on both the priestly and prophetic view of cultic activities.

15.Also compare in this regard Hilber (2012:517): 'Numerous passages in the writin prophets criticize the cult in Israel and Judah, and debate has emerged over whether the prophets were opposed to the cult in principle or were only critical of cultic malpractice and disregard for ethical duty'.

16.In his monograph on Ethics in Ancient Israel, Barton (2014:1-2) defines ethics as follows: "Ethics" may mean one of two closely related things. It may refer to the moral code of a society, and thus be more or less synonymous with "morality". In that sense all societies have ethics or "an ethic". But it may also be used to refer to reflection on morality from a philosophical perspective, and thus be equivalent to "moral philosophy"; and in this sense it is clear that not all societies have "ethics" ... This book does concern itself to some extent with ethics in the first sense: much will be said about the moral norms of ancient Israelite society in various periods. But its primary focus is on ethics in the second sense. I want to argue that ethics in ancient Israel forms an as yet unwritten chapter in the history of ethics'.

17. During this time, most scholars followed Wellhausen in his negative interpretation of the cult. He inter alia infers as follows: 'Den Eindruck, den man aus den geschichtlichen Büchern gewinnt, verschärfen die Propheten. Sie leugnen, daß Jahve auf Opfer Wert lege und daß er sie befohlen habe ... Daß der Opferritus nicht den Inhalt der Thora bilde, dürfen die Propheten als selbstverständlich ansehen' (2001:56, 58). Cf. also Wellhausen (2004:174): 'Der Kultus war das heidnische formalised pro-cultic externalised religion being advocated by priestly circles (Hrobon 2010:1; cf. also Carroll Rodas 2012:185; Hilber 2012:517; Udoekpo 2017:xviii). ${ }^{18}$ More recent Old Testament scholarship has been more inclined to take the edge off this harsh either-or position in a more nuanced manner (cf. e.g. Barton 2007:116-121; Carroll Rodas 2005:215227, 2012:185; Ernst 1994:97-197; Klawans 2006:75-100). This interpretation could suggest that both the prophetic and priestly circles echo the same concept of the cult, whereby they basically share the same theological and religious perspectives (Hrobon 2010:1).

For the sake of this discussion, it is useful to take De Vaux's definition of the cult, according to which the cult consists of 'all those acts by which communities or individuals give outward expression to their religious life, by which they seek and achieve contact with God' (1961:271). The cult thus consists of rituals which 'mean the outward forms which this service takes' (1961:271). ${ }^{19}$ In a study on the social meaning(s) of sacrifice, Janzen (2004) argues that:

$[R]$ ituals, sacrifice among them, communicate the worldview and morality of particular social groups that compete with other societies for the allegiance of individuals. I will refer repeatedly to the social meanings of rituals, by which I mean the communication of ritual expression or rhetoric, and which includes social significance - the worldview of a particular group - and social function - the group's moral system. Sacrifice, like other rituals, communicates social meaning to its participants, and like other rituals the meaning it expresses is a communication of the way one social group understands the world to be and, therefore, the moral actions that its members should adopt. (p. 4)

If the cult is then understood as the Torah's vertical dimension and ethics as its horizontal dimension, one can agree with Jensen's (2006) interpretation, namely that:

$[T]$ he vertical and horizontal dimensions go together, equally expressions of God's will; and this in turn means that where the horizontal dimension (social justice, etc.) is lacking, the vertical dimension (worship, sacrifice) is impossible. (p. 29; cf. also Hrobon 2010:3)

Although Hrobon (2010:3) infers that the relationship between the cult and ethics may be more complicated, he still assumes that cultic concepts - as defined in the Priestly

Element in der Religion Jahves, größtenteils erst bei der Einwanderung in Palästina von den Kanaaniten entlehnt; und er blieb vor dem Exil immer das Band, welches Israel mit dem Heidentum verknüpfte, eine stete Gefahr für die Moral und den Monotheismus. Er wurde daher von den Propheten bekämpft, aber er ließ sich nicht einfach abschaffen'. McKane (1982:265) puts to words Wellhausen's perspective of einfach abschaffen'. McKane (1982:265) puts to words Wellhausen's perspective of the opposition between the prophet and the cult as follows: 'There is, perhaps, something of an essential, irreconcilable opposition between the prophet and stitutional religion in Wellhausen's understanding of the matter. The prophet's searing truthfulness and dismissal of surface appearances is so uncompromising and highly individual that it cannot receive an institutional expression. Hence, the relation of the great Hebrew prophets to Judaism is, according to Wellhausen, paradoxical: they were the fathers of Judaism, they prepared the way for the Law, but this embodiment was incapable of preserving or expressing the spirit of prophecy'.

18.Not long ago Ronald Hendel also advocated a return to the priest-prophet dichotomy. With regard to the prophetic condemnations of sacrifice, he states as follows: 'although many scholars in recent years have attempted to read these passages as something less than a rejection of ritual, I would agree with William McKane that these scholarly attempts do not do justice to the texts whereas the priests that these scholarly attempts do not do justice to the texts... Whereas the priests see a correspondence and mutuality between ritual and ethics, the classica prophets contrast the ethical with the ritual' (Hendel 1995:190-191) (cf. also
McKane [1982:251-266] who advocates a return to Wellhausen's interpretation.

19.Compare Hrobon (2010:12): 'Ritual is used in OT scholarship as a general label for offering sacrifices, purificatory procedures, and related activities such as fasting or prayer'. 
literature - are the idea behind these ethical appeals. This perspective-namely that cultic concepts are the main driving force behind the cult-critical statements in the prophetic writings - may offer a fresh alternative to the interpretation of these texts (Hrobon 2010:4). This perspective is supported by, amongst others, Milgrom (1991:731) when he states ' $[t]$ rue, the ethical is bound up with and inseparable from the ritual, and the Pentateuchal codes make no distinction between them'.

It is appropriate to voice a note of concern at this point (Klawans 2006), namely the:

$[H]$ ard-and-fast distinction between ritual and ethics has prevented scholars from appreciating the degree to which ritual and ethics are inherently connected - and virtually inseparable - when it comes to sacrifice. Sacrifice became anathema for the prophets not because God preferred a loftier form of worship, nor because the temple service was performed by people who had other things on their minds. (p. 249)

The problem was thus not the offering of sacrifices per se, but inter alia the misappropriation of proceeds and the exploitation of the poor.

For this discussion, it is important to keep in mind that the textual portrayal of conflicts and differences of opinions between the priests and the prophets were indeed a reality although we should take care not to generalize too soon (Klawans 2006:98). It can be taken as a scholarly consensus that the biblical sources, whether they come from a priestly or prophetic hand, went through extended periods of textual development. Furthermore, ancient Israel had different social groups, which consisted of, amongst others, groups of priests and circles of prophets. Any reconstruction and/or portrayal of this complicated historical situation should not reflect linearity but a diversity within these social groups. It can furthermore be inferred that (Klawans 2006):

[T]he biblical tradition comprises various preexilic priestly and prophetic traditions that have been transmitted, redacted, and glossed by various priestly and prophetic scribal circles in exilic and postexilic milieus. What these sources provide, therefore, are assorted windows into disputes among ancient Israelites; and these windows are half-open and partially curtained ones at that. (p. 99) ${ }^{20}$

God's presence was of primary interest to both the priests and the prophets, whether this was attained through ritual performance or not (Hrobon 2010:32). In the ancient Israelite mind, sacrifice was regarded on the one hand as a solution to the problem of transgression, but on the other hand it gave expression to their religious ideals and hopes, namely to imitate the divine to maintain the divine presence amongst them. One can say this was a shared denominator in both the priestly as well as prophetic tradition (Klawans 2006:73).

20. In this regard, Groenewald (2009:58) infers as follows: 'we hear the voices of both the priests and the prophets through the literati, namely through the books composed and edited to present a particular message and ideology by the small elite literate circle responsible for writing and book production'. This also endorse what Ringgren (1948:18) stated: 'there is no essential difference between the prophets and, for instance, the books of law, as to the conception of holiness. The prophets obviously accepted the cultic notion of holiness, as it is preserved to us in the ritual laws of the Pentateuch'.
Although the priests were concerned with God's presence in the temple - to guard against ritual impurity - God's presence outside of the temple was the concern of the prophets and therefore they placed the emphasis on moral impurity. ${ }^{21}$ The prophets are far from being anti-ritualistic when they take the purpose of rituals serious by overemphasising moral purity versus moral impurity, that is, the defilement of the ritual caused by grave sins. In fact, their zeal for ethics is the result of their zeal for God's presence in the midst of his people. ${ }^{22}$ In this regard Hrobon (2010) infers that:

$[T]$ he value of ethics for the prophets was determined by cult, not vice versa as is often assumed. In such case, one can think of moral (im)purity as the ethical dimension of cult. (p. 36)

According to the $\mathrm{HB}$, holiness is one of the most important characteristics of $\mathrm{YHWH}$, and holiness is inseparable from his presence (Hrobon 2010:37). ${ }^{23}$ In the priestly mind, the categories of holy versus profane, purity versus impurity, are very important theological concepts. In summary, 'that which is "holy" (Heb. qadosh) is either God or something that has been consecrated or set apart for use with reference to the divine' (Kessler 2013:341-342). Holiness as a category is not only attributed to God but also used to describe human beings, possessions, places and festivals. According to this concept, temple, land, as well as the people belong to God, and therefore, their holiness is also derived from God (Hrobon 2010:37-38). Holiness, according to Milgrom's viewpoint, is a positive concept which is associated with God's character, and subsequently, he desires holiness for humankind: 'You shall be holy, for I am holy' (Lv 20:26). What the HB calls [holy], means imitatio Dei, namely a 'life of godliness', that which humankind cannot really achieve. This imitation of God, that is to say his holiness, demands of humankind to follow the ethics that are associated with God's character (Milgrom 1991:731).

We can thus endorse the following statement when Hrobon (2010) infers that:

$[I] \mathrm{n}$ the Priestly literature cultic concepts such as purity/ impurity, holiness of the land substantiate ethics. It seems that if the focal point of cult is YHWH's presence (with which holiness is intrinsically connected), the reason for an ethical appeal in conjunction with ritual practice is the capacity of certain immoral behaviour to effect the purity of the people, the land, the city or the sanctuary. The laws that regulate such behaviour are therefore cultic in nature, so one can think of them as the promulgation of the ethical dimension of cult. (p. 72)

It seems that ethics and cult are related in a similar manner in the prophetic books. The ethical appeals in the prophetic

21. Hilber $(2012: 513)$ stresses the important point that the writing prophets can easily be misunderstood as being antiritualistic, but consideration of their broader message indicates that they were deeply concerned that the cult function properly, and their visions often portray a vibrant and promising future for temple worship'.

22.In this regard, Oswalt (1998:505) infers as follows: 'This is ultimately what biblical religion is all about: the presence of God. It is not first of all a system of ideas or a system of ethics. It is first of all the inbreaking of God into our lives, and that inbreaking will change all our ideas and all our behavior'.

23.In this regard, Gammie (1989:195) infers as follows: 'Holiness in Israel was not first and foremost something for human beings to achieve, but rather that characteristic of ineffability possessed only by God, the Lord of Hosts, the Holy One of Israel'. See also Brueggemann (2015:263-265). 
books are the result of the fact that unethical behaviour has a negative impact on YHWH's presence, which, as has been said, is linked to his holiness.

\section{Criticism of the cult in the book of Amos (5:21-24) ${ }^{24}$}

The book of Amos is well known for its message of social justice, and in Amos 5:24, it is formulated in a striking way: 'Let justice roll on like a river, righteousness like a never failing stream' (Snyman 2012:19; Udoekpo 2017:xvii). ${ }^{25}$ The prophet Amos, as is often done in the prophetic literature, warns the people against misconduct and malpractices in their worship practices. Amos addresses a specific form of religion, which, according to his understanding, is hypocritical, focussed on people's self-interest and less interested in the true worship of YHWH (5:21ff.). According to Amos, all those rituals performed for the sake of religion are not true religion, and therefore, it is useless to perform religious acts without authenticity - especially when the society is characterised by social injustices (Snyman 2012:21).

In this passage, justice and righteousness are elevated above religious expression (Nogalski 2011:320). These verses formulate YHWH's opposition to religious and cultic activities which are not accompanied by justice and righteousness, and this chapter even concludes with a threat to exile the people beyond Damascus (v. 27) (Sweeney 2000:238). Verses 21-24 do not imply that Amos condemned Israel's worship because it was cultic, but because of the absence of justice and righteousness. ${ }^{26}$ Therefore, the existing cultic practices are called sinful (4:4-5), useless (5:21-23) and doomed (5:4f.) (Mays 1985:109; cf. Weiss 1995:212).

In Eidevall's opinion, this rejection of cultic practices should not be interpreted as a general rejection of all cultic activity, but as a very specific reference to sacrifices which were offered in the temples located in Israel and as a reference to the major cultic sites in the Northern Kingdom (2016:109). ${ }^{27}$ If understood in this way, this Amos text becomes a theological

24.Compare Weiss (1995:200-201) regarding the demarcation of this unit: According to the accepted view, Amos 5:21 is the beginning of a literary periscope referring to the cult ... Indeed, vv. 21-24 and vv. 25-27 are both phrased as divine speech, and just as the major part of the first passage (vv. 21-23) speaks of the cult, so does the second passage ... The following analysis of the four verses confirms that v. 24 is in fact the conclusion and will show that the periscope is a complete unity, reflecting cact the con calculated design non 21-24 are a litera constructed according to the same scheme'.
com this passage in Amos and is

25.According to Carroll Rodas (2001:87), the chiastic structure gets lost in the English translation. The verse literally reads as follows: 'and let roll down like water justice, and righteousness like an ever-flowing stream'

26.Nogalski (2018:113) also concluded as follows: 'One may infer from this statement a theology that rejects ritual sacrifice if the life of the worshipper does not reflect commitment to justice and righteousness' (cf. also Carroll Rodas 2005:216-217). Regarding the cult-critical statements in Micah 6:6-8, O'Brien (2015:89) states as follows: 'This passage is not a radical challenge to the sacrificial system as many have claimed, since even cultures and religious systems that value the sacrificial system stress the values of justice and righteousness. This "both-and" attitude toward sacrifices and ethics is evident in the common invocation of "justice" in the Psalms The covenantal requirements set forth in the Torah make no distinction between ethics and ritual, presenting all norms for Israel's behaviour as commandments from YHWH'.

27.Also compare Nogalski (2018:113): 'The sanctuary in Bethel ... is not surprising given its role in the book of Kings as a symbol of the Northern Kingdom's rejection of Jerusalem as the sole temple of YHWH. It is not surprise, therefore, to see Bethel condemned in Amos because it represents an improper altar from a Judean perspective'. interpretation and explanation for the disaster and subsequent trauma of the catastrophe of $722 \mathrm{BCE}$. The gist of their sins and crime, which caused $\mathrm{YHWH}$ to reject the sacrificial cult of Israel, is summarised in terms of a lacking concern for justice and righteousness (v. 24). It should thus be emphasised that 'the offering of sacrifices is not seen as one of the sins that provoked the divine anger!' (Eidevall 2013:41).

Another possibility may also be that the image of justice and righteousness that 'roll on' like an ever-flowing stream of water may be seen as an allusion to the 'Day of YHWH' (cf. 5:18-20), which can be interpreted as the coming punishment. The divine punishment of the 'Day of $\mathrm{YHWH}^{\prime}$, which will take the form of a forthcoming disaster, is unavoidable (Eidevall 2012:116; cf. also Barker 2012:139-140; Eidevall 2013:38-41; Nogalski 2018:114). Conspicuous is the fact that this text does not refer to Judah or the temple cult in Jerusalem (Eidevall 2016:109). If a later date is the preferred choice, namely after the fall of Samaria in 722 BCE, it is possible to interpret this text as a 'piece of pro-Judean propaganda, which explains why YHWH rejected the Northern Kingdom (which made it possible for Judah to become the new Israel)' (Eidevall 2013:41).

Verse 25, which links to the subject of sacrifice in verse 22, begins with a rhetorical question: 'Did you bring to me sacrifices and offerings the forty years in the wilderness, $\mathrm{O}$ house of Israel?' This question immediately creates a canonical tension as it implies a negative answer in assuming that the people did not sacrifice during the time in the wilderness. Canonically, however, the narratives in the Torah point to the fact that sacrifices were offered during the 40 years in the wilderness (cf. Ex 24; Ex 32; Lv 9 etc.) (Nogalski 2011:322). In Mays' (1985) opinion, this:

$[O]$ pening question is a denial that sacrifice and offering were the mode of Israel's relation to Yahweh during the wilderness years. Seen in connection with v. 24 it implies that in those normative original years Israel responded to Yahweh with obedience, and produced justice and righteousness instead of presenting sacrifice. (p. 111)

In this regard, Sweeney (2000) states as follows:

One must recall, however, that the Pentateuch presents this period as one of rebellion against $\mathrm{YHWH}$ 's promises of the land (Nm 10-14); the rebellion of Korah (Nm 16); and the apostasy at Baal Peor (Nm 25). It would appear then that YHWH cites the sacrifices of the wilderness period as an indication that sacrifice alone does not constitute a proper relationship to $\mathrm{YHWH}$, especially when the people reject $\mathrm{YHWH}$ and turn to other gods. (p. 241)

This statement, in verse 25 , thus would only make sense if it is dated in an exilic or post-exilic setting ${ }^{28}$ as it relativises the significance of the sacrificial cult in a situation in which large groups of $\mathrm{YHWH}$ worshippers could not get access to a 'legitimate' temple (Eidevall 2016:110; cf. also Eidevall 2012:163-169).

28.Schart (1998:81-82) suggests a later dating, as well as Jeremias (2007:82), who infers as follows: '... ist zur Zeit, da die Tradenten seine Worte niederschrieben, in Gestalt der Deportationen der Assyrer längst Wirklichkeit geworden ...'. 


\section{Criticism of the cult in the book of Isaiah (1:10-17.18-20)}

This unit is demarcated by means of a twofold introductory imperative call to instruction directed towards the nation's rulers as well as the people (v. 10) (Sweeney 1996:79). This imperative call in verse 10 characterises the basic structure of the first part of this unit, which forms the prophet's presentation of a speech of YHWH (vv. 11-17). The audience, identified as the 'rulers of Sodom' and 'people of Gomorrah', is addressed by the prophet and instructed to hear and to listen (or 'give ear') to the 'word of YHWH' and the 'Torah of our God' ${ }^{29}$ Verses 11-17 constitute the prophet's quotation of YHWH's speech: it commences in verse 11a with a speech formula ('says $\mathrm{YHWH}^{\prime}$ ) and is combined with a first-person address form, which is directed to a second-person plural audience. Verse 18 introduces a new unit, which can be described as a proposal for a legal proceeding which is concluded in verse 20 with another YHWH-speech formula (Sweeney 1996:82).

If this unit is compared with the preceding one (1:2-3.4-9), a dramatic shift can be detected. The prophet's comparison with Sodom and Gomorrah (v. 10) is used in a totally different manner than in the preceding unit where this comparison was used to indicate total destruction (Tull 2010:61). The Isaianic idea of the 'remnant' was connected in verse 9 with the tradition of Sodom and Gomorrah (cf. also Groenewald 2011a:101). This comparison makes two points clear to the reader: (1) the near extinction of the people, like it happened to Sodom and Gomorrah, and (2) the wickedness of the people, like the people of Sodom and Gomorrah. The total annihilation of the two cities Sodom and Gomorrah - as is chronicled in Genesis 18-19 $19^{30}$ - was clearly a more or less proverbial text in ancient Israel, as the number of allusions in other books clearly indicates (Loader 1990:58-59). It thus seems a tertium comparationis for the complete nature of the destruction (cf. also Groenewald 2011a:101). In the comparison in verse 9, Jerusalem was almost like Sodom, but in verse 10 the city has now become Sodom, and its rulers have now become Sodom's rulers (Tull 2010:60). In this verse, the hearers are not only called upon to listen to the 'word of $\mathrm{YHWH}^{\prime}$, but more specifically 'the Torah of our God' (Tull 2010:61).

The text is characterised by its skilled rhetoric. The thesis is not presented immediately, but builds up gradually. It commences with a call to attention, followed by a statement which is designed to shock the faithful, namely the outrageous claim that God does not want the many sacrifices brought and offered to him by the devout (Tull 2010:62). The YHWH speech commences with a number of questions that address the different forms of public worship, sacrifices and wholeburnt offerings (vv. 11.13) as well as question the legitimacy

29.Also compare Groenewald (2013:702-706) for 'word of YHWH' and 'Torah of our God' in Isaiah 1:10 and 2:3.

30.Also compare Loader (1990:46-47) who defines the function of this text (Gn 18-19) as follows: 'to argue that God punishes wickedness, but that he also respects individual innocence in the midst of mass guilt, so that it is even possible that the guilty may be saved because of the innocent. Mass as well as individual guilt is guilty may be saved because of the innocent. Mass as well as individual guilt is
punished, but not at the price of justice. So God is vindicated in the face of doubt about his righteousness when he intervenes in the affairs of humans'. of pilgrimages to the temple (v. 12). It furthermore condemns communal celebrations (vv. 13-14) and criticises the value of individual prayers (v. 15). This critique is followed by a call upon the people to purify their lives (v. 16) and an explication of the specific conduct YHWH expects of his people in the form of a divine lesson (v. 17) (Tull 2010:62-63; cf. also Lafferty 2012:71-78).

The list of worship practices and types of sacrifices mentioned indicate the prophet's familiarity with the temple rituals in Jerusalem; even prayer is included (Tull 2010:62). Isaiah, however, mixes them altogether and indeed does not follow any priestly protocol to reject them all as an abomination before YHWH. According to the prophet, Israel's offerings are judged as 'abhorrent' and 'useless' in the eyes of God, as well as its liturgy a 'trampling' in God's courts. God's reaction is portrayed in strong language: He is 'tired' and 'disgusted' because of these religious practices, and Israel's carefully orchestrated rituals even fill him with revulsion (Childs 2001:19).

In the reading sequence of this unit, it is only in verse 15 that the reader is informed that God does not have a problem with the rituals as such, but the problem is in the hands of its performers: 'your hands are full of blood' (Tull 2010:62). The prophetic attack is thus specifically directed to all religious distortions occurring in Jerusalem (cf. Childs 2001:19); as even Isaiah's rejection of prayer makes this very clear. The problem indeed is the lack of social ethics of the community of the faithful and not with the rituals themselves (Tull 2010:64).

The rhetorically strong (and shocking) list of accusations is now followed by a list of nine imperatives in verses 16-17 outlining the actions that the prophet believes God wants to see (Tull 2010:62). Profound changes are expected of Israel and actions required are of two distinct types. Firstly, in the centre of the appeal directed towards Israel, we find three general statements about good and evil (v. 16): It is clear that the prerequisite for a restored relationship with $\mathrm{YHWH}$ is for evil to be replaced by good. Ritual purification should take place to restore what has been defiled and to make acceptable to the holy God what was made unacceptable to him (Brueggemann 1998:18).

The word ' $w a \mathrm{sh}^{\prime 31}$ is found in the HB in an everyday ritual, as well as in an ethical sense, and the parallel term, translated as 'make yourselves clean', is narrower in its scope as it only refers to moral purity (cf. Tull 2010:62). It is also important to keep in mind that the prophet was not opposed to ritual cleansing, as Isaiah 6:5 indicates to us. On the contrary, the faith community should be undefiled and make use of all available means to become ritually purified and acceptable to YHWH. Secondly, the prophet Isaiah takes socio-economic-

31.According to Difransico (2016:44-45), " $i] \mathrm{t}$ is likely that it is the bloody hands mentioned in v. 15 that are the object of the washing in v. 16 ... The washing is likely intended to apply to the whole person with blood-stained hands representative of the people's sinful state ... the washing commanded here is utilized as a metaphor for repentance and return to the Lord ... was intended to point them to a solution to their sin through metaphoric language that draws on the life experience of washing of bathing with water'. 
political issues seriously. ${ }^{32}$ In the last four lines in verse 17, the concern for justice to the oppressed, the orphan and the widow is very clear. This triad refers to those in the Judean society who are the weak and the vulnerable; they are in other words the ones who are politically and economically excluded and without an advocate to represent their just cause in society. Clearly, God does not only expect holiness (right worship) but also ethical behaviour (justice) (Brueggemann 1998:18-19).

In the final composition of Isaiah chapter 1, the introductory verses 2-3 indicated an important theme the reader will encounter, namely Israel's self-destructive stupidity (Brueggemann 1998:19). ${ }^{33}$ In this composition of chapter 1, verses 4-9 and 10-17 form a detailed explication of the claim of verses 2-3, namely the self-destruction of Israel and subsequent traumatisation. ${ }^{34}$ Verse 18 ends this long scenario and returns to the legal proceeding, which had started in verse 2 . A real change is necessary and possible: 'The bloody colour of sin can turn to the innocence of snow. What has been the crimson of mark of disobedience can become innocence again' (Brueggemann 1998:20). Verses 19-20 make it clear that Israel indeed only has two choices according to the tradition in Deuteronomy 30:15-20: they can choose obedience, or they can continue to be rebellious (cf. also 1:2). Israel can choose life or they can choose death (Brueggemann 1998:20).

Isaiah 1:10-20 belong to the compositional introduction of the book of Isaiah, namely Isaiah chapters 1-4 (Berges 2012:44-45). This introduction is not the literary creation of either an Isaiah or pre-exilic tradents, but was created in the post-exilic period as a composition in which the future of the cleansed Zion and its population stand at its centre. In this regard, it is important to take note of the fact that a 'remnant' is all that remains: 'If the Lord of Hosts had not left us a few survivors, we would have been like Sodom and become like Gomorrah' (1:9). The fact that the tradents indicate that there is only a 'remnant' left, which can save the people of God from total collapse (1:9), is an indication of the level of traumatisation present in these layers that already occur early in this introductory chapter of the book of Isaiah. The key words 'Sodom' and 'Gomorrah', as well as the adoption of the We-group's perspective ('Torah of our God' - 1:10), cement the connection that is made between 1:10-17.18-20 (on the one hand) and 1:2-3.4-9 (on the other hand) (Berges 2012:52). The We-group, with this Torah of God, addresses the 'rulers of Sodom' and the 'people of Gomorrah' and indicates that repentance could still be

32. Compare Stulman and Kim (2010:30): "The call for justice is central in Isaiah and throughout the prophetic traditions ... This emphasis occurs ... also in the opening oracle. Hearing the divine voice, the readers would also recall the overriding expectation for a just and righteous life'

33.Also compare Groenewald (2011b:1-6). According to DiFransico (2016:44-45) ' $[s]$ in and its consequences are the problems being addressed in the rebuke of chapter 1 , not ritual uncleanness, and thus the solution posed is a solution to $\sin$, not a ritual purification method. Thus, the source domain from which this metaphor draws on is non-cultic, non-ritual washing, i.e. simple, everyday bathing of the body or body parts with water'.

34.Compare Stulman and Kim (2010:31): 'Isaiah perceives YHWH's voice not only as a master but also as a parent with deep emotional affection. It is as though God struggles with human stubbornness as much as human pain'. possible (1:18-20). The fact that this opening formula 'Hear the word of $\mathrm{YHWH}^{\prime}(1: 10)$ appears only once more in the book of Isaiah, namely in Isaiah 66:5 again is an indication that the authors of chapters 65-66 (i.e. the servants) positioned themselves towards 1:10-20 and deliberately created these last chapters of the book as a dialogical reply to 1:10-20 (Berges 2012:52-53). The critique of the excess of offerings and cultic zeal (in 1:10-15) shows implicitly the reaction of post-exilic Israel to a traumatised reality: in spite of all the sacrifices and cultic efforts, a better feature has not arrived yet. Therefore, the Torah of the We-group puts its emphasis on the superiority of ethics to all cultic activities (Berges 2012:53).

\section{Conclusion}

This contribution can be concluded with the following brief remarks. It is possible to identify an important rhetorical strategy underlying in both texts which were discussed here (Am 5:21-24 and Is 1:11-15). It can be presupposed that both the prophet and/or author and the first addressees of these texts must have regarded the cult, and subsequent sacrificial practices, as an appropriate way to worship YHWH, the God of Israel. It would have been impossible to communicate with any deity in the Ancient Near East without sacrificial offerings and/or prayers (Eidevall 2013:44).

Whichever way we date these texts, their rhetorical strategy is shockingly effective. Had these texts been written before the disaster of $587 \mathrm{BCE}$, they predict the catastrophe of the destruction of the temple in Jerusalem. But on the other hand, if they were composed after the disaster of $587 \mathrm{BCE}$ had struck the city and the temple, we can interpret them as a theological explanation of this disaster, and the subsequent trauma experienced by the people of Judah and Jerusalem. Both texts (Amos and Isaiah) want to portray a comforting message to their readers informing them that the trauma and disaster which had struck were not because of YHWH's powerlessness in the face of the enemy's deities. YHWH would have been able to protect his temple or his own people, had it not been for this rejection of the late pre-exilic cult and sacrificial practices. The catastrophe - and subsequent trauma - was caused by the iniquity of the people and their leaders in that specific historical situation (Eidevall 2013:45). As a final point, coming to terms with the debilitating and long-lasting effects of trauma is neither simple nor uncomplicated. In Amos and Isaiah, the textual response by naming the cause of the disaster is a first step on the long and difficult journey of recovery. By naming the cause of the tragic events helps the community to move beyond its trauma and thus become a powerful symbol of survival in a traumatised world.

\section{Acknowledgements Competing interests}

The author has declared that no competing interest exist. 


\section{Author(s) contributions}

I declare that I am the sole author of this research article.

\section{Ethical consideration}

This article followed all ethical standards for a research without direct contact with human or animal subjects.

\section{Funding information}

This research received no specific grant from any funding agency in the public, commercial, or not-for-profit sectors.

\section{Data availability statement}

Data sharing is not applicable to this article as no new data were created or analysed in this study.

\section{Disclaimer}

The views and opinions expressed in this article are those of the authors and do not necessarily reflect the official policy or position of any affiliated agency of the authors.

\section{References}

Barker, J.D., 2012, 'Day of the Lord', in M.J. Boda \& J.G. McConville (eds.), Dictionary of the Old Testament Prophets. A compendium of contemporary Biblical scholarship, the Old Testament Prophets. A compendium of cont

Barton, J., 2007, 'The Prophets and the cult', in J. Day (ed.), Temple and worship in Biblical Israel. Proceedings of the Oxford Old Testament Seminar, LHB/OTS 422, pp. 111-122, T\&T Clark, London.

Barton, J., 2014, Ethics in Ancient Israel, Oxford University Press, Oxford.

Becker, E.-M., 2014, 'Trauma studies' and Exegesis: Challenges, limits and prospects', in E.-M. Becker, J. Dochhorn \& E.K. Holt (eds.), Trauma and traumatization in individual and collective dimensions: Insights from Biblical Studies and Beyond SANt 2, pp. 15-29, Vandenhoeck \& Ruprecht, Göttingen.

Berges, U., 2012, The Book of Isaiah. Its Composition and Final Form, Hebrew Bible Monographs 46, Sheffield Phoenix Press, Sheffield.

Brueggemann, W., 1998, Isaiah 1-39, Westminster Bible Companion, Westminster John Knox, Louisville, KY.

Brueggemann, W., 2015, 'Why the Old Testament must not go away', Word \& World 35(3), 262-275.

Carlson, N.A., 2015, 'Lament: The Biblical Language of Trauma', Cultural Encounters 11(1), 50-68. https://doi.org/10.11630/1550-4891.11.01.50

Carr, D.M., 2014, Holy Resilience. The Bible's Traumatic Origins, Yale University Press, New Haven, CT.

Carroll Rodas, M.D., 2001, 'Seeking the virtues among the Prophets: The Book of Amos as a Test Case', Ex Auditu 17, 77-96.

Carroll Rodas, M.D., 2005, 'Can the Prophets shed light on our Worship Wars? How Amos evaluates Religious Ritual', Stone-Campbell Journal 8(2), 215-227.

Carroll Rodas, M.D., 2011, 'Amos', in M.D. Coogan (ed.), The Oxford Encyclopedia of the Books of the Bible, pp. 26-32. Oxford University Press, Oxford.

Carroll Rodas, M.D., 2012, 'Ethics', in M.J. Boda \& J.G. McConville (eds.), Dictionary of the Old Testament Prophets. A Compendium of Contemporary Biblical Scholarship, the Old Testament Prophets. A Compendium of COn
pp. 185-193, IVP Academic, Downers Grove, IL.

Childs, B.S., 2001, Isaiah, OTL, Westminster John Knox, Louisville, KY.

De Vaux, R., 1961, Ancient Israel. Its life and institutions, transl. J. McHugh, Darton Longman and Todd, London.

DiFransico, L.R., 2016, Washing Away Sin. An Analysis of the Metaphor in the Hebrew Bible and its Influence, Biblical Tools and Studies 23, Peeters, Leuven.

Eidevall, G., 2012, Sacrificial Rhetoric in the Prophetic Literature of the Hebrew Bible, Edwin Mellen Press, Lewiston, NY.

Eidevall, G., 2013, 'Rejected sacrifice in the Prophetic literature: A rhetorical perspective', Svensk Exegetisk Årsbok 78, 31-45.

Eidevall, G., 2016, 'A farewell to the Anticultic Prophet: Attitudes towards the cult in the Book of Amos', in L.-S. Tiemeyer (ed.), Priests and Cults in the Book of the Twelve, Ancient Near East Monographs, pp. 99-114. SBL Press, Atlanta, GA.

Ernst, A.B., 1994, Weisheitliche Kultkritik. Zu Theologie und Ethik des Sprüchebuchs und der Prophetie des 8. Jahrhunderts, Biblisch-Theologische Studien 23, Neukirchener Verlag, Neukirchen Vluyn.
Esterhuizen, E., 2017, 'A study of the tension between despair and hope in Isaiah 7 and 8 from a perspective of trauma and posttraumatic growth', unpublished DTh thesis, Unisa, Pretoria, viewed 20 May 2019, from http://uir.unisa.ac.za/ thesis, Unisa, Pretor
handle/10500/22263.

Frechette, C.G. \& Boase, E., 2016, 'Defining "Trauma” as a useful lens for Biblical Interpretation', in C.G. Frechette \& E. Boase (eds.), Bible through the Lens of Trauma, Semeia Studies 86, pp. 1-23, SBL Press, Atlanta, GA

Gammie, J.G., 1989, Holiness in Israel, Overtures to Biblical Theology, Fortress Press, Minneapolis, MN.

Groenewald, A., 2009, 'Psalm 51 and the criticism of the cult: Does this reflect a divided religious leadership?', Old Testament Essays 22(1), 47-62.

Groenewald, A., 2011a, 'Isaiah 1:4-9 as a post-exilic reflection', Journal for Semitics 20(1), 87-108.

Groenewald, A., 2011b, 'Isaiah 1:2-3, ethics and wisdom. Isaiah 1:2-3 and the Song of Moses (Dt 32): Is Isaiah a prophet like Moses?', HTS Teologiese Studies/Theological Studies 67(1), Art. \#954, 1-6. https://doi.org/10.4102/hts.v67i1.954.

Groenewald, A., 2013, 'The significance of הרות (Isa 2:3) within Isaiah 2:1-5: The relationship of the first overture (1:1-2:5) to the book's conclusion (Isa 65-66)', Old Testament Essays 26(3), 695-717.

Groenewald, A., 2017, 'Micah 4:1-5 and a Judean Experience of Trauma', Scriptura 116(2), 55-65, viewed 25 April 2019, from http://scriptura.journals.ac.za/pub/ article/view/1329.

Groenewald, A., 2018, "Trauma is suffering that remains'. The contribution of trauma studies to Prophetic Studies', Acta Theologica Suppl 26, 88-102. https://doi. org/10.18820/23099089/actat.Sup26.5

Gutierrez, G., 1988, A Theology of Liberation: History, Politics and Salvation [English 1971, Teologia de la liberacion: Perspectivas, transl. and ed. Sister C. Inda and J. Eagleson], Orbis Books, Maryknoll, NY.

Gutierrez, G., 1999, 'The task and content of liberation theology', transl. J. Condor, in C. Rowland (ed.), The Cambridge Companion to Liberation Theology, pp. 19-38, Cambridge University Press, Cambridge.

Hendel, R.S., 1995, 'Prophets, Priests, and the efficacy of ritual',' in D.P. Wright, D.N. Freedman \& A. Hurvitz (eds.), Pomegranates and Golden Bells: Studies in Biblical, Jewish, and Near Eastern Ritual, Law, and Literature in Honor of Jacob Milgrom, pp. 185-198, Eisenbrauns, Winona Lake, IN.

Hilber, J.W., 2012, 'Liturgy and cult', in M.J. Boda \& J.G. McConville (eds.), Dictionary of the Old Testament Prophets. A Compendium of Contemporary Biblical Scholarship, pp. 513-524, IVP Academic, Downers Grove, IL.

Hrobon, B., 2010, Ethical dimensions of cult in the Book of Isaiah, BZAW 418, De Gruyter, Berlin.

Janoff-Bulman, R., 1992, Shattered assumptions. Towards a new psychology of trauma, The Free Press, New York, NY.

Janoff-Bulman, R., 1999, 'Rebuilding shattered assumptions after traumatic life events: Coping processes and outcomes', in C.R. Snyder (ed.), Coping: The psychology of what works, pp. 302-323, Oxford University Press, New York, NY.

Janzen, D., 2004, The social meanings of sacrifice in the Hebrew Bible: A study of four writings, BZAW 344, Walter de Gruyter, Berlin.

Janzen, D., 2012, The violent gift. Trauma's Subversion of the Deuteronomistic History's Narrative, LHB/OTS 561, T\& T Clark, New York, NY.

Jensen, H., 2006, Ethical dimensions of the Prophets, Liturgical Press, Collegeville, MN.

Jeremias, J., 2007, Der Prophet Amos, 2. Auflage, ATD 24, 2, Vandenhoeck \& Ruprecht, Göttingen.

Kessler, J., 2013, Old Testament Theology. Divine Call and Human Response, Baylor University Press, Waco, TX.

Klawans, J. 2006, Purity, sacrifice, and the temple. Symbolism and supersessionism in the study of ancient Judaism, Oxford University Press, Oxford.

Katongole, E., 2017, Born from Lament. The theology and politics of hope in Africa, Eerdmans, Grand Rapids, MI.

Lafferty, T.V., 2012, The Prophetic critique of the priority of the cult: A study of Amos 5:21-24 and Isaiah 1:10-17, Pickwick, Eugene, OR.

Loader, J.A., 1990, A tale of two cities. Sodom and Gomorrah in the Old Testament, early Jewish and early Christian traditions, J.H. Kok, Kampen.

Mays, J.L., 1985, Amos, OTL, SCM Press, London.

McKane, W., 1982, 'Prophet and institution', ZAW 94(2), 251-266. https://doi. org/10.1515/zatw.1982.94.2.251

Migliore, D.L., 2014, Faith seeking understanding. An introduction to Christian Theology, 3rd edn., Eerdmans, Grand Rapids, MI.

Milgrom, J., 1991, Leviticus 1-16: A new translation with introduction and commentary, Anchor Bible 3, Doubleday, New York, NY.

Moltmann, J., 1999, God for a secular society. The public relevance of Theology [1997, Gott im Projekt der modernen Welt. Beiträge zur öffentlichen Relevanz der Theologie, transl. M. Kohl], SCM Press, London.

Morrow, W., 2011, 'Deuteronomy 7 in postcolonial perspective: Cultural fragmentation and renewal', in B. Kelle, F.R. Ames \& J.L. Wright (eds.), Interpreting exile: Interdisciplinary studies of displacement and deportation in Biblical and modern contexts, Society of Biblical Literature Ancient Israel and its Literature 10, pp. 275-293, SBL Press, Atlanta, GA.

Nogalski, J.D., 2011, The Book of the Twelve: Hosea - Jonah, Smyth \& Helwys Commentary, Smyth \& Helwys, Macon, GA.

Nogalski, J.D., 2018, Introduction to the Hebrew Prophets, Abingdon Press, Nashville, TN. 
O’Brien, J.M., 2015, Micah, Wisdom Commentary 37, Liturgical Press, Collegeville, MN.

O'Connor, K.M., 2010, 'Reclaiming Jeremiah's violence', in J.M. O'Brien \& C. Franke (eds.), The Aesthetics of violence in the Prophets, LHB/OTS 517, pp. 37-49, T \& T Clark, London.

O'Connor, K.M., 2012, Jeremiah. Pain and promise, Fortress Press, Minneapolis, MN.

Osuagwu, T., 2016, 'An ideological-critical interpretation of justice and righteousness in Amos 5', Unpublished MA thesis, University of Pretoria, viewed 10 May 2019, from http://hdl.handle.net/2263/63000.

Oswalt, J., 1998, The Book of Isaiah: Chapters 40-66, NICOT, Eerdmans, Grand Rapids, MI.

Rambo, S., 2010, Spirit and trauma. A theology of remaining, Westminster John Knox, Louisville, KY.

Ringgren, H., 1948, The Prophetical conception of Holiness, Uppsala Universitets Ârsskrift 12, A.-B. Lindquist, Uppsala.

Rowland, C., 1999, 'Introduction: The theology of liberation', in C. Rowland (ed.), The Cambridge Companion to Liberation Theology, pp. 1-16, Cambridge University Press, Cambridge.

Rumfelt, J.L., 2011, 'Reversing fortune: War, psychic trauma, and the promise of narrative repair', in B. Kelle, F.R. Ames \& J.L. Wright (eds.), Interpreting exile Interdisciplinary studies of displacement and deportation in Biblical and moder contexts, Society of Biblical Literature Ancient Israel and its Literature 10 pp. 323-342, SBL Press, Atlanta, GA.

Schart, A., 1998, Die Entstehung des Zwölfprophetenbuchs: Neubearbeitungen von Amos im Rahmen schriftenübergreifender Redaktionsprozesse, BZAW 260, Walter de Gruyter, Berlin.

Scheffler, E.H., 1990, 'The social ethics of the Lucan Baptist (Lk 3:10-14)', Neotestamentica 24(1), 252-267.

Scheffler, E.H., 1993, Suffering in Luke's Gospel, AThANT 81, Theologischer Verlag, Zürich.

Scheffler, E.H., 2005, 'Deuteronomy 15:1-18 and Poverty in (South) Africa', in E. Otto \& J. le Roux (eds.), A critical study of the Pentateuch. An encounter between Europe and Africa, ATM 20, pp. 97-115, Lit-Verlag, Münster.

Scheffler, E.H., 2009a, 'War and violence in the Old Testament', in J.T. Fitzgerald, F.J. Van Rensburg \& H.F. Van Rooy (eds.), Animosity the Bible, and Us: Some European, North American and South African Perspectives, Global Perspectives on Biblical Scholarship 12, pp. 1-17, SBL Press, Atlanta, GA

Scheffler, E.H., 2009b, 'Jesus the Jew for today: A Hermeneutical exercise', Acto Patristica et Byzantina 20(1), 194-214. https://doi.org/10.1080/10226486.2009. 11879104

Scheffler, E.H., 2011a, 'Pleading poverty (Or: Identifying with the poor for selfish reasons): On the ideology of Psalm 109', Old Testament Essays 24(1), selfish reasor.

Scheffler, E.H., 2011b, 'Luke's view on poverty in its ancient (Roman) economic context: A challenge for today', Scriptura 106, 115-135. https://doi. org/10.7833/106-0-152

Scheffler, E.H., 2012, 'Poverty in the book of Proverbs: Looking from above?', Scriptura 111(3), 480-496. https://doi.org/10.7833/111-0-30.

Scheffler, E.H., 2013a, 'Poverty eradication and the Bible in context: A serious challenge', Studia Historiae Ecclesiasticae 24, 129-153.

Scheffler, E.H., 2013b, 'Of poverty prevention in the Pentateuch as a continuing contemporary challenge', Verbum et Ecclesia 34(2) (2013b) Art. \#869, 14 pages. https://doi.org/10.4102/ve.v36i1.1478

Scheffler, E.H., 2014, 'Reflecting on (non-)violence in the Book of Deuteronomy in (Old Testament) Canonical context', Old Testament Essays 27(2), 579-596.
Scheffler, E.H., 2015a, 'The poor in the Psalms: A variety of views', Verbum et Ecclesia 36(1), Art. \#1478, 9 pages. https://doi.org/10.4102/ve.v36i1.1478

Scheffler, E.H., 2015b, 'Reflecting on Jesus' teaching on forgiveness from a positive psychological perspective', HTS Teologiese Studies/Theological Studies 70(1), Art. \#2982, 10 pages. https://doi.org/10.4102/hts.v70i1.2982

Scheffler, E.H., 2015c, 'The Historical Jesus as peacemaker between Judaism, Christianity and Islam', Neotestamentica 49(2), 261-296.

Scheffler, E.H., 2016a, 'The Historical Jesus and (Non)violence: A contemporary challenge', in J. Hunter \& J. Kügler (eds.), The Bible and Violence in Africa, BiAS, pp. 91-115, University of Bamberg Press, Bamberg.

Scheffler, E.H., 2016b, 'Albert Schweitzer and the historical Jesus: Reflecting on some misconceptions', in I.J.J. Spangenberg \& C. Landman (eds.), The legacies of Albert Schweitzer reconsidered, Studia Historiae Ecclesiasticae Book Series 1 , pp. 189-217, AOSIS, Cape Town. https://doi.org/10.4102/aosis.2016. tlasr11.07

Scheffler, E.H., 2017, 'Royal care for the poor in Israel's First History: the Royal Law (Deuteronomy 17:14-20), Hannah's Song (1 Samuel 2:1-10), Samuel's warning (1 Samuel 8:10-18), David's attitude (2 Samuel 24:10-24) and Ahab and Naboth (1 Kings 21) in Intertext', Scriptura 116/2 (2017: Special Edition), 160-174. https:// doi.org/10.7833/116-2-1317

Scheffler, E.H., 2018, 'Various views on peace in the twelve minor Prophets', in H.-J. Fabry (ed.), The Books of the Twelve Prophets. Minor Prophets - Major Theologies, BETL 295, pp. 501-517, Peeters, Leuven.

Schreiter, R.J., 2016, 'Reading Biblical texts through the lens of resilience', in C.G. Frechette \& E. Boase (eds.), Bible through the Lens of Trauma, Semeia Studies 86, pp. 193-207, SBL Press, Atlanta, GA.

Smith-Christopher, D.L., 2002, A Biblical theology of exile, Overtures to Biblical Theology, Fortress, Minneapolis, MN.

Snyman, S.D., 2012, 'Amos, Prophet of God's justice', in H.G.L. Peels \& S.D. Snyman (eds.), The lion has roared. Theological themes in the Prophetic Literature of the Old Testament, pp. 17-26, Wipf \& Stock, Eugene, OR.

Stulman, L. \& Kim, H.C.P.K., 2010, You are my people. An introduction to Prophetic literature, Abindgon Press, Nashville, TN.

Sweeney, M.A., 1996, Isaiah 1-39 with an introduction to prophetic literature, FOTL 16, Eerdmans, Grand Rapids, MI.

Sweeney, M.A., 2000, The Twelve Prophets. Volume I: Hosea - Jonah, Berit Olam, Liturgical Press, Collegeville, MN.

Tull, P.K., 2010, Isaiah 1-39, Smyth \& Helwys Bible Commentary, Smyth \& Helwys, Macon, GA.

Udoekpo, M.U., 2017, Rethinking the Prophetic critique of Worship in Amos 5 for Contemporary Nigeria and the USA, Pickwick, Eugene, OR.

Weiss, M., 1995, 'Concerning Amos' Repudiation of the cult', in D.P. Wright, D.N Freedman \& A. Hurvitz (eds.), Pomegranates and Golden Bells: Studies in Biblical, Jewish, and near Eastern Ritual, Law, and Literature in Honor of Jacob Milgrom, pp. 199-214, Eisenbrauns, Winona Lake, IN.

Wellhausen, J., 2001, Prolegomena zur Geschichte Israels, reprint of the 6th edn., 1927, Walter de Gruyter, Berlin.

Wellhausen, J., 2004, Israelitische und jüdische Geschichte, reprint of the 9th edn., 1958, Walter de Gruyter, Berlin.

Westermann, C., 1974, 'The role of Lament in the Theology of the Old Testament', Interpretation 28(1), 20-38. [Translation: Die Rolle der Klage in der Theologie des Alten Testaments, in C. Westermann, 1974, Forschung am Alten Testament. Alten Testaments, in C. Westermann, 1974, Forschung am Alten Testament.
Gesammelte Studien II (Hrsg. R. Albertz \& E. Ruprecht), pp. 250-268. Chr. Kaiser Gesammelte Studien II (Hrsg. R. Albertz \& E. Rupr
Verlag, München. (Theologische Bücherei 55).] 